\title{
Emotional challenges to masculinity in the 1930s Callide Valley closer settlement, Australia
}

\author{
MARGARET COOK \\ School of Law and Society, \\ University of the Sunshine Coast; \\ Honorary Research Fellow, \\ La Trobe University and University of Queensland
}

\section{Abstract}

When the Callide Valley closer settlement scheme was opened in central Queensland in 1927 its design was based on a gendered rural ideal. A farming man was to be hard-working, stoic and tough, able to withstand the unpredictable climate and environmental conditions to tame the land, build the new nation and provide for his family; acts by which he could construct and demonstrate his settler masculinity, while cultivating the land. Through an analysis of settler correspondence to a Queensland government enquiry in 1934, this article problematises the myths of masculinity in this rural community to explore the emotional and mental strain on male settlers when the environment posed limits to settler economic and agricultural success.

Keywords: masculinity, environmental history, gender, rural history, settler society, Queensland

\section{Introduction}

In 1934 a farmer, William Cahill, informed a Queensland government enquiry that owing to bad seasons and very small return from the land, I have not received enough to purchase food to the average standard of living. This is not all, at times I have not had any money at all and have had to receive Government rations, or otherwise starve. ${ }^{1}$

1 William Vivian Cahill, Confidential Reports of Selectors. ID 1013452. Queensland State Archives (QSA), Brisbane. 
Cahill lived on a 202-acre farm called 'Verona' near Jambin in the Callide Valley in central Queensland where he grew cotton and maize (corn). Like many in the district he was struggling to make ends meet, saddled with debt, and facing constant expenditure and failing crops during years of drought. Hunger and poverty were the realities facing Callide Valley families.

This individual story of the struggle to farm in a subtropical land of drought and floods, where the soil and pests presented constant challenges to settler agricultural endeavours, is indicative of the plight facing many of the region's farmers in 1930s. Less than a decade earlier, the Queensland Government carved 1 million acres of land in the Upper Burnett and Callide Valley regions (Figure 1) into small agricultural holdings to form a new closer settlement. Typical of the interwar years, the government's advertisements promoted the region as having 'unlimited possibilities', ${ }^{2}$ celebrating the ideal climate and fertile soil. This was a place of promise where men who were unafraid of hard work and possessed the characteristics of stoicism and grit would surely succeed. Yet for many in the 1930s, the Callide Valley became a place where the assurance of success proved elusive. The climate would thwart farmers' aspirations and test the physical and mental fortitude of the settlers. ${ }^{3}$ It would also challenge notions of masculinity in rural Australia.

Masculinity is central to settler Australia's foundational myth whereby men (not women) worked the land, tamed and transformed the environment. In accordance with what John Hirst described in the 1970s as the 'pioneer legend', masculine labour 'was central to the nation-making activity of agricultural settlement' and stereotypical 'manly' qualities of courage, endurance and perseverance were required to survive. ${ }^{4}$ More recent scholarship rejects these notions of biological essentialism that categorise men and women into a fixed duality. Most notably, the feminist theorists R. W. Connell and Judith Butler (among others) both maintain that masculinity and femininity are cultural constructs. 'Gender is performative', manifested through the behaviour of men, ${ }^{5}$ and in this rural settlement in Queensland masculinity was demonstrated by 'taming' the land through farming. ${ }^{6}$ In his study of masculinity in the nineteenth-century Queensland frontier settlements, the historian Robert Hogg has shown that this was a place where masculine ideals were tested and reworked.

\footnotetext{
2 Queensland Government Intelligence and Tourist Bureau, The Upper Burnett and Callide Valley Districts, Queensland (Brisbane: Queensland Government Intelligence and Tourist Bureau, 1925), 5-10.

3 This idea is a central theme in Richard Brome et al., Mallee Country: Land, People, History (Melbourne: Monash University Publishing, 2020), 102.

4 J. B. Hirst, 'The Pioneer Legend', Historical Studies 18, no. 71 (1978): 316-17, doi.org/10.1080/10314617 808595595.

5 R. W. Connell, Masculinities (Sydney: Allen and Unwin, 1995), 44; Judith Butler, Gender Trouble: Feminism and the Subversion of Identity (New York: Routledge, 1999), 179.

6 Cultural geographers have been more attentive to rural gender relations, questioning the nature of gender itself and its social construction in rural communities. See Jo Little, 'Rural Geography: Rural Gender Identity and the Performance of Masculinity and Femininity in the Countryside', Progress in Human Geography 26, no. 5 (October 2002): 665, doi.org/10.1191/0309132502ph394pr.
} 
Here was a stage on which men could 'perform' manliness, in accordance with the hegemonic notions of masculinity. While some conformed, many men could not live up to the ideal. Hogg's work challenges idealised notions of masculinity, suggesting that these ideals were constructed and perpetuated to foster social cohesion and control, and to maintain the national mythology, ${ }^{7}$ rather than reflecting reality.

This article builds on Hogg's analysis of the pastoralist frontier and examines a second wave of settlement in the twentieth century - the Callide Valley settlement scheme in central Queensland. Here the normative gendered behavioural codes of the nineteenth century persisted, promulgated in the government's promotional material for the scheme. ${ }^{8}$ But men struggled to live up to these gendered ideals and, as I have shown elsewhere, women often undertook physical labour on these farming properties. ${ }^{9}$ While Hogg complicates frontier masculinity, my work adds nature's agency to the male settlers' difficulties in fulfilling prescribed masculine roles (breadwinner and farmer) and characteristics (strength, endurance, hard work and stoicism). In doing so I engage with the work of environmental historians who seek to identify how human 'experience is moulded by the landscapes and environments in which people live and labour'.$^{10}$ In particular, I am influenced by Katie Holmes' gendered analysis of settlement in the Mallee region in Victoria and how the land created the so-called 'Mallee man'. ${ }^{11}$ Similarly, this article questions how the environment and climate in the Callide Valley settlement shaped its male settlers, who were not only Britons, and often circumscribed their efforts to perform their masculinity.

In 1934 the Queensland Government instituted a Commission of Inquiry to investigate the Upper Burnett and Callide Valley settlement scheme after the region experienced three years of severe drought, which nearly crippled the project. This was an economic enquiry with a standardised survey form designed and distributed to farmers to collate economic statistics: stock numbers, acreage under crop, yields, gross and net incomes, and assets. A total of 955 settlers returned the form, while

\footnotetext{
7 Robert Hogg, Men and Manliness on the Frontier: Queensland and British Columbia in the Mid-Nineteenth Century (Basingstoke: Palgrave Macmillan, 2012), 4, 177-9.

8 Queensland Government Intelligence and Tourist Bureau, The Upper Burnett and Callide Valley Districts, Queensland: Large Areas of Agricultural, Dairying, and Grazing Land Available for Selection (Brisbane: Government Printer, 1923), 17.

9 Margaret Cook, 'Challenging gender stereotypes in Queensland's Callide Valley: Settlers, patriarchy and environment', History Australia, Published online 15 February (2021), doi.org/10.1080/14490854.2021.1878911.

10 Katie Holmes and Heather Goodall, 'Introduction: Telling Environmental Histories', in Telling Environmental Histories: Intersections of Memory, Narrative and Environment, ed. Katie Holmes and Heather Goodall (Basingstoke: Palgrave Macmillan, 2017), 5, doi.org/10.1007/978-3-319-63772-3.

11 Katie Holmes and Kylie Mirmohamadi, 'Howling Wilderness and Promised Land: Imagining the Victorian Mallee 1840-1914', Australian Historical Studies 46, no. 2 (2015), 191-213, doi.org/10.1080/1031461X.2015. 1037320; Katie Holmes, 'Making Masculinity: Land, Body, Image in Australia's Mallee Country', in Visions of Australia: Environments in History, ed. Christof Mauch et al., RCC Perspectives 2 (2017): 39-48; Katie Holmes, "The "Mallee-Made Man": Making masculinity in the Mallee lands of south eastern Australia', Environment and History 27, no. 2 (May 2021).
} 
some respondents voluntarily took the opportunity to write accompanying letters further describing their personal circumstances. These forms and letters, stored in the state government's archives, offer an insight into the human (and emotional) experience of closer settlement in northern Australia between 1927 and 1934. This article considers the mental and emotional strain on these settlers as they attempted temperate farming methods in a subtropical climate. The historian Rebecca Jones has considered the emotional impacts of drought - the anger, fear, hope and uncertainty shared by many settler farmers in southern Australia-using personal diaries and correspondence. These sources, Jones argues, 'draw the reader into the writer's intimate world, providing a portrait of individuals' everyday thoughts and feelings unmediated by hindsight'. ${ }^{12}$ A study of these Queensland farmers' letters add to our growing understandings of the psychological toll of closer settlement in the first half of the twentieth century.

Written for a government enquiry that was subject to public hearings, these Callide Valley letters lack the intimacy of private letters that correspondents might have written to family or friends. As an historian, I was left wondering about the anguish that may have otherwise been contained in such private letters. As much of the correspondence included a plea for economic assistance, they may disproportionately dwell on their negative lived experiences. While the correspondence cannot be considered 'begging letters', as per the Irish charity letters analysed by Lindsey Earner-Byrne, or Thomas Sokoll's Essex pauper letters, ${ }^{13}$ the Callide Valley letters were written to explain straitened experiences and request assistance from the authorities that had encouraged them to settle there. These letters corroborate the power imbalance revealed in the pauper letters-supplicant writers requesting government assistance - and are similarly crafted to present the writer as being of good character and worthy of aid. ${ }^{14}$ Like Earner-Byrne's correspondents, these Callide farmers were self-aware of their identity and the society in which they were writing. ${ }^{15}$

The English language was a further limitation for correspondents, as some were Russian, German, Italian or Albanian, demonstrating the wave of European migration to the Callide Valley during the 1920s. English fluency may have constrained the details correspondents could provide, but the Council of Agriculture attempted

12 Rebecca Jones, 'Uncertainty and the emotional landscape of drought', International Review of Environmental History 4, no. 2 (2018): 15, doi.org/10.22459/IREH.04.02.2018.03; Rebecca Jones, Slow Catastrophes: Living with Drought (Melbourne: Monash University Press, 2017).

13 Lindsey Earner-Byrne, Letters of the Catholic Poor: Poverty in Independent Ireland, 1920-1940 (Cambridge: Cambridge University Press, 2017), doi.org/10.1017/9781316841198; Lindsey Earner-Byrne, “'Dear father my health has broken down”: Writing Health in Irish Charity Letters, 1922-1940', Social History of Medicine 28, no. 4 (2015): 849-68, doi.org/10.1093/shm/hkv061; Thomas Sokoll, 'Negotiating a living: Essex Pauper Letters from London, 1800-1834', International Review of Social History 45 (2000): 19-46, doi.org/10.1017/S0020859 000115275 .

14 Earner-Byrne, “'Dear father my health has broken down”, 851.

15 Earner-Byrne, Letters of the Catholic Poor, 2. 
to mitigate this problem by appointing E. Harding (Secretary of the Central Queensland District Executive of the Council of Agriculture) to assist settlers with their submissions. His role was to visit farms, and deliver and collect forms. However, as the responses are handwritten, this suggests that Harding had little direct involvement with the preparation or contents of the submissions. Although the surviving letters may not fully reflect the situation of the correspondents, they nonetheless provide insights into the lives of these farmers by offering examples of voices of ordinary people. ${ }^{16}$

These voices - that is the authors of the forms and letters to the government enquirywere largely those of male settlers, with a handful of female lessees. Writing of the drought experiences she gleaned from settler diaries from the twentieth century, Jones argues that, in keeping with prevailing gender norms, it was 'acceptable, even desirable, for women to write openly and reflect on emotional experiences', but notes a reticence in men's correspondence to do the same. ${ }^{17}$ In contrast, these Callide Valley letters do reveal the anguish of men, which is more surprising given that their audience was likely to be other men (government officials assessing a land settlement scheme) - hardly a private space to be sharing feelings of inadequacy or personal hardship. Just as Jones' letter-writers convey fears of drought, the Callide Valley farmers document the uncertainty of farming in an unfamiliar climate, subject to drought and flood, a land where crops failed, stock died and settlers struggled to survive. Jones' subject material records the 'feeling of loss of control and mastery, of helplessness and a sense of futility', ${ }^{18}$ emotions evident in the Callide Valley also.

I have used these questionnaires and letters elsewhere to discuss settler understandings of climate, and gender stereotypes in early twentieth-century Australia. ${ }^{19}$ This article re-interprets these sources to ask: in a culture where men were expected to be stoic, resilient and strong as proof of their masculinity, how did men cope emotionally when their farms failed and strained their physical and mental strength? Some were broken by the experience, while others endured, but it is unlikely that any were unchanged. As this article shows, these experiences informed the written testimonies of Callide Valley men, who articulated the challenges they faced in ways that were contrary to the prevailing masculine ideal of rural Australia.

16 Tim Hitchcock, 'Review: A New History from Below', History Workshop Journal 57, no. 1 (2004): 297, doi. org/10.1093/hwj/57.1.294; Martyn Lyons, 'A New History from Below? The Writing Culture of Ordinary People in Europe', History Australia 7, no. 3 (2010), doi.org/10.2104/ha100059.

17 Jones, 'Uncertainty and the emotional landscape of drought', 15.

18 Ibid., 19.

19 Margaret Cook, 'Perceptions of a "Normal” Climate in Queensland, Australia (1924-34)', Rural History 31 (2020): 67-77, doi.org/10.1017/S0956793319000219; Cook, 'Challenging Gender Stereotypes'. 


\section{The Callide Valley}

In the 1850s, squatters occupied the country of the Gangulu Nation people and cleared the land for beef cattle grazing. In 1923, under the Upper Burnett and Callide Valley Settlement Scheme, 3 million acres of land was resumed from the pastoralists for a closer settlement scheme, designed to break large pastoral holdings into small leases for working family farms of between 160 and 320 acres (65 and 130 hectares) for agriculture, including cotton production and dairying. ${ }^{20}$ This settlement scheme followed a history of similar schemes introduced throughout Australia since the 1860s, including the soldier settlement schemes after the First World War. Common to all such schemes was the desire to populate and improve the unproductive, empty 'waste lands' by luring white (ideally British) settlers to the region. ${ }^{21}$ The scheme's design was inherently gendered: hard-working, progressive young men would lease farms, bringing their wives and children, who they would support financially, thereby occupying and taming the land through agriculture to build the settler state.

One million acres were settled in the Callide Valley, an area of roughly 4,400 $\mathrm{km}^{2}$ traversed by rivers and creeks. It extended from the Dawes Range in the south to the Don River in the north, bounded by the Calliope Range on the east and the Banana Range on the west (Figure 1). The climate is subtropical, characterised by erratic rainfall, floods and droughts. Within this vast region, the range of soil types includes alluvial, clay (black soil) and sand, with flat or hilly outcrops. By the 1920s, much of the land had been cleared for cattle grazing, although remaining vegetation included areas of scrub that comprised ironbark, bloodwood, box gum, wilga (Geijera parviflora) and belts of brigalow (Acacia harpophylla).

Land was made available through ballot, and settlers rushed to the region in the late 1920s, lured by state government promises of 'vast areas of fertile land' that would 'would grow practically anything. ${ }^{22}$ Promoters of the scheme, perhaps concerned that the land would look unappealing to immigrant eyes, explained that the scrub was 'not to be regarded as stunted vegetation covering useless barren land', but a 'tropical jungle in rich volcanic soil-ideal dairying and agricultural land'. ${ }^{23}$ Railway construction in the 1920s created the towns of Goovigen, Jambin, Argoon, Callide, Thangool and Biloela (the region's administrative hub) with roads, bridges and buildings further altering the landscape. As with all Australian settlement

\footnotetext{
20 W. L. Payne, Report and Recommendations Following on an Economic Investigation by the Land Administration Board of the Upper Burnett and Callide Valley Lands (Brisbane: Government Printer, 1929); Morning Bulletin, 20 September 1930, 5. Note that the Upper Burnett lands were further south and were settled before the Callide Valley.

21 For example, Geoffrey Bolton, Spoils and Spoilers (Sydney: Allen \& Unwin, 1981); Tom Griffiths, Forests of Ash: An Environmental History (Cambridge: Cambridge University Press, 2011), 32-5.

22 W. G. Graham, Under Secretary for Public Lands, 21 February 1919. ID 7937. QSA.

23 Queensland Government Intelligence and Tourist Bureau, The Upper Burnett and Callide Valley Districts (1925), 15-16.
} 
schemes, government conditions were imposed, requiring settlers to undertake large-scale land clearing, fencing and other improvements, as well as annual upkeep, or face forfeiture. Hardwood trees became fencing while the remaining scrub was ring-barked and felled, then burned, destroying the native grasses, as the land was made ready for agriculture. Cleared and fenced land created a patchwork of family farms across the region, fulfilling the nation-building vision of successive state governments to make central Queensland an agriculturally productive region, populated and defendable against foreign invasion. ${ }^{24}$

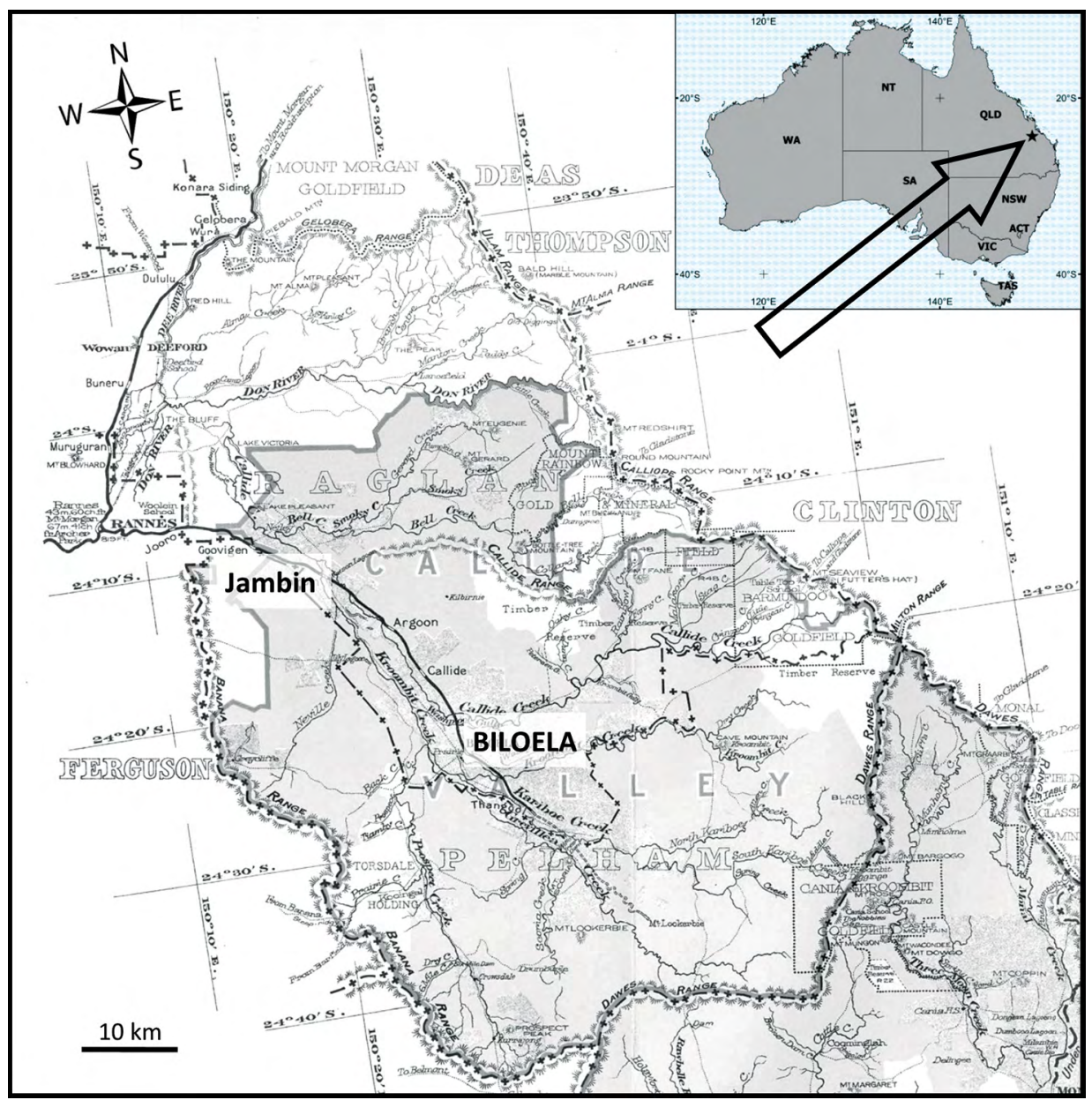

Figure 1: The Callide Valley, Queensland.

Source: Nick Cook.

24 David Cameron, 'Closer Settlement in Queensland: The Rise and Decline of the Agrarian Dream, 1860s-1960s' in Struggle Country: The Rural Ideal in Twentieth Century Australia, ed. Graeme Davidson and Marc Brodie (Melbourne: Monash University Press, 2005), 1-3. See also W. Ross Johnston, The Call of the Land, (Brisbane: Jacaranda, 1982), 49, 165. 
Early settlers relied on dairy cows, pigs and mixed agriculture for their livelihoods. But it was cotton that the government promoted, as the crop was thought to be drought tolerant owing to its long taproot. Cotton required little capital outlay, and as such it was considered a cash crop to supplement dairying and low-scale agricultural production. Although it could be planted on burnt-off scrubland amongst the stumps and logs, ideally the land would be tilled and ploughed, with the seed planted in furrows. Farmers replaced 'natural grasses' with 'artificial grasses' (to use the nomenclature on the survey forms), as imported Rhodes grass (Chloris gayana) supplanted the native Wiregrass (Aristida sp.) and Wallaby grass (Austrodanthonia caespitosa) as the preferred stock feed.

The local brigalow, with its lateral root structure, 'defied the axe' and tested many settlers. If cleared, the stumps of mature trees produced suckers and dense regrowth that proved even more difficult to remove. ${ }^{25}$ Settlers reported constant struggles with this persistent acacia. In his submission Clarke reported, 'during the last drought about 80 per cent of the Rhodes grass died out and brigalow suckers got control', undoing months of tree clearing. ${ }^{26}$ Similarly, J. A. Shaw, who leased 1,530 acres (619 hectares) at Goovigen, wrote to the Commission of Inquiry:

Apart from spending all my own money, what I borrowed and what I made on the place in building up the farm, I have had to keep and maintain a family of 11 children; ring barking has not been the success I expected, as now I have to spend more than ever on going over it and taking out the suckers; I also find that after taking 3 crops off a peace [sic] of land it is almost an impossibilite [sic] to keep it clean, to run and keep my place in fair order. I reckon it cost me $£ 3 / 10 / 0$ per week apart from my living. ${ }^{27}$

In Shaw's own battle with nature, the brigalow was winning. Brigalow thrived in deep cracking clay soils prone to 'gilgais', an Aboriginal word for a small water hole, and in this region they were plentiful. The Callide Valley correspondence repeatedly refers to 'melonhole gilgai' that helped sustain the drought-tolerant brigalow. ${ }^{28}$ Shaw's words demonstrate he believed the environment limited his capacity to 'keep and maintain' his family.

Time and experience were to disprove several of the promoters' claims of unlimited agricultural potential, fertile and watered soil. The grains, tubers and citrus fruit, cited as potentially successful crops, were well beyond the capacity of the land. Before the introduction of irrigation in the 1960s, dairying and dryland (non-irrigated) cotton production depended entirely on rainfall. The farmers' reports to the 1934

25 Clive McAlpine and Leonie Seabrook, 'The Brigalow', Queensland Historical Atlas, 22 October 2010, www. qhatlas.com.au/content/brigalow, accessed 12 March 2021.

26 A Clarke, Confidential Reports of Selectors. ID 1013473. QSA.

27 J. A. Shaw, Confidential Reports of Selectors. ID 1013780. QSA.

28 T. R. Paton, 'Origin and Terminology for Gilgai in Australia', Geoderma, 11 (1974): 221-42, doi.org/10.1016/ 0016-7061(74)90019-6. 
Commission of Inquiry reveal the trials brought by environmental factors, a litany of problems from too little or too much rain, or its poor timing, as well as deficient soils and harsh temperatures. A major flood occurred in 1928, followed by three 'good' years, then successive years of drought and crop failures between 1931 and 1933. Settlers faced glutinous black soil or porous sandy soils. Others had to contend with steep hills, gullies and 'very stoney' land, complaining that 'any heavy rain that does happen to fall just runs away and the evaporation is terrific' ${ }^{29}$ Dry seasons rendered the ground too hard to plough and the roads rough. Drought killed grass and entire crops failed, milking ceased, and stock was sold, agisted or died..$^{30}$ Noxious weeds, by contrast, flourished. ${ }^{31}$

Heavy rain at times proved equally problematic, drowning stock and crops, sweeping away fences and making roads impassable, which isolated both people and markets for up to four months, especially in areas of bog-prone black soil. ${ }^{32}$ Some holdings were more prone to flooding, P. Cavanagh recording that his forested area all flooded, leaving the 'heavy sodden country' too wet to plant. He lost crops to floods in three successive years. ${ }^{33}$ Settlers reported that the rains brought 'pests', prickly pear (Opuntia and Nopalea spp) and Noogoora burr (Xanthium strumarium), the seeds carried in the flood waters, prevented the pre-season burn of the felled scrub and delayed planting. ${ }^{34}$ These pests, however, were a product of British colonisation. Prickly pear had arrived on the continent thanks to the First Fleet in 1788, and the burr was imported to Noogoora Station in Queensland in the 1870s, most likely as a contaminant in imported cotton seed. ${ }^{35}$ Both were spread by humans, animals and streams and took root on cleared land, permanently altering the land and the local ecology.

Stories of drought and flood, poor soil and complaints of suckers, wallabies and other pests are repeated throughout the settlers' questionnaires and letters, highlighting the agency of nature in a settlement that challenged the survival of both settlers and the settlement scheme. Despite years of hard work, by the early 1930s many settlers lived in poverty-stricken conditions, a situation they blamed on a 'series of

\footnotetext{
29 Daniel Smith, Confidential Reports of Selectors. ID 1013790. QSA.

30 E. Lord, Confidential Reports of Selectors. ID 1013643. QSA; 'The Callide Tragedy', Morning Bulletin, 23 March 1934, 6.

31 H. J. Tucker, Confidential Reports of Selectors. ID 1013827. QSA.

32 C. Morgan, Jnr, Confidential Reports of Selectors. ID 1013665. QSA; E. T. Simpson, Confidential Reports of Selectors. ID 1013785. QSA.

33 P. J. Cavanagh, Confidential Reports of Selectors. ID 1013465. QSA.

34 L. C. Wallace, Confidential Reports of Selectors. ID 1013844. QSA; C. Shelton, Confidential Reports of Selectors. ID 1013782. QSA; H. Leighton, Confidential Reports of Selectors. ID 1013635. QSA; H. J. Tucker, Confidential Reports of Selectors. ID 1013827. QSA.

35 Jodi Frawley, 'Containing Queensland prickly pear: Buffer zones, closer settlement, whiteness. Journal of Australian Studies 38, no. 2 (2014): 141, doi.org/10.1080/14443058.2014.896824; Western Australia Department of Primary Industries and Regional Development, 'Noogoora Burr; what you should know', 2018, www.agric. wa.gov.au/declared-plants/noogoora-burr-what-you-should-know, accessed 12 March 2021.
} 
bad seasons' ${ }^{36}$ These environmental challenges had a dire effect on some settlers, and it is evident that many men considered their failure to provide for their family an abrogation of their masculine duty. Their letters and submissions record their despair, frustration and sense of helplessness.

\section{The lived experience}

Due to the unreliable rainfall that looks good on paper, agricultural farming has proved very unprofitable[.] [I]t makes good farmers the heaviest losers due to the amount of work and expense incurred in proper farming from which they have had no return during the last three years.

This situation, described by farmer Cornelius Shelton, faced many settlers in central Queensland's Callide Valley in the 1930s. Shelton had moved to the region in 1927, leasing two 'selections' or land holdings ( 436 acres or 176 hectares) 4.5 miles $(7.2 \mathrm{~km})$ from the town of Biloela where he and his wife, Eva, grew cotton, maize, potatoes, fodder crops and broom millet, and milked 45 dairy cows.

Shelton recorded that the land proved 'uneven in quality', ranging from sand to dark alluvial soil, and they faced frequent floods, with 110 acres ( 45 hectares) 'under flood water in any fair year'. Floods came when there was a 'good coat of grass just before the winter', leaving it useless and coated in silt. He struggled with Noogoora burr that had infiltrated the watersheds upstream of his property, as every flood brought 'a fresh supply of burr seed along' that took root on the floodplain. In the drought years of 1932 and 1933, Shelton recorded financial losses of $£ 23$ and $£ 82$ respectively, his problems exacerbated by having the additional costs of 'shifting his cattle to relief country' as his crops failed. By 1934 he had a $£ 630$ bank overdraft and owed $£ 972$ to the Lands Department, local shire, storekeeper and Vacuum Oil Company. He maintained that a 'district which has been subjected to 3 years on end drought should not be classed as a farming district and farmers should not be enticed to the district for that purpose'. ${ }^{37}$ In his words, he had 'a poor chance of making good without considerable concessions'. By 1938, Shelton gave up on cotton, turning to dairy farming in the hope of better results. ${ }^{38}$

R. H. Applin faced a similar plight after purchasing his first selection near Biloela in 1930, and a second by 1931, a total of 476 acres (193 hectares). One selection comprised brigalow scrub, the other timbered with 'heavy black, melon holy soil', land covered in gilgais. Applin planted 35 acres (14 hectares) of cotton in both 1931 and 1932 with no result, 18 bales of seed cotton being produced off

\footnotetext{
36 'Plateau of Poverty', Telegraph, 20 March 1934, 9. See Cook, 'Perceptions of a "Normal" Climate' for a detailed account of the Callide Valley weather in this period.

37 C. Shelton, Confidential Reports of Selectors. ID 1013782. QSA.

38 'Cotton Growing', Daily Mercury [Mackay], 6 April 1940, 2.
} 
40 acres (16 hectares) in 1933. He produced 20 bags of maize in 1933, but after costs (including crown dues, seed and feed for his eight horses), he recorded no net income between 1930 and 1932, as debts mounted. Applin's original block of 171 acres (69 hectares) could carry one beast per 10 acres, the additional block considerably less. He informed the enquiry that the grazing value of his land was lower than most, as in drought 'a fall of rain has little effect on the black soil which becomes abnormally hard and cracked under dry conditions'. Excessive rain caused bogs, and he wrote: 'It is no exaggeration to say that every time a beast lifts its foot it obliterates an area of grass'. The roads became impassable and prevented access to markets in town. He fared little better in drought, when he was left with 'no grass whatsoever', forced to hand feed his horses until they were sent for agistment. Once dry, the black soil with its 'melon-holy' character made it extremely difficult to break up for planting and it required four years to plough more than one furrow. It was only possible to plant in dry conditions, but black soil dries quickly, and if too dry the seeds do not germinate. Applin informed the enquiry: 'I do not consider it a suitable or really economic soil to use for agricultural purposes but am forced to use a portion of it'. The government sank bores and required settlers to pay for them regardless of success. Farmers considered the cost exorbitant, and water charges, survey fees and rent increased their debt. Applin maintained that the government had made more money from his land than he had. 'Had I been drawing rations' (unemployment benefits), 'I would have been better off'. Only off-farm work and 'the strictest personal economy and sacrifice' had enabled him 'to carry on at all'. He asked to be allowed to sell one of his leases so that he could concentrate on dairy farming. ${ }^{39}$

Unfortunately, Applin's selection of two portions 8 miles $(13 \mathrm{~km})$ apart had contributed to his difficulties in running a profitable farm. What is clear in Applin's story is his depiction of nature's role in his predicament. Drought and flood, he believed, were his main problems, rendering the soil too wet or too dry to be productive. The cost of the government water facility was an ongoing economic strain, but that too could be attributed to unreliable rainfall, as could the failure of the crops and the need for agisting horses. Maintaining horses, cattle and imported crops on this land tested the suitability of both land and farmer. Applin, in his correspondence, is quick to blame circumstances (largely environmental) for any failure, rather than his own inexperience or weaknesses.

Both Shelton and Applin were struggling to survive in poor seasons on blocks that were of questionable agricultural fertility. These records give an insight into both families' financial strain as they survived on government aid or borrowed money, a situation they considered demoralising. Applin, in particular, questioned his own value, as despite his years of hard work only the government enjoyed the proceeds 
of his labour. But the toll on these male settlers proved more than financial. While few overtly mention their health in the correspondence, some provided evidence of physical and mental strain, providing an insight into the emotional landscape of the settlement. ${ }^{40}$

One farmer who admitted health problems was Edward Miers. Born in 1895 at Jondaryan, southern Queensland, he served in the First World War and married Alice Gaze (born in Wyandra in 1902) at Drillham in Queensland in 1921. Together they had son, Edward, the following year. ${ }^{41}$ The family moved to 'Rangeview' in Thangool in 1932 during a drought. On his 515 acres (208 hectares), Miers ran dairy cattle and planted a small area of cotton. Apart from an unsuccessful and expensive water bore the government installed and forced Miers to pay for, his 'chief difficulties lay in the bad run of seasons and the low cost of butter'. He wrote: 'the last two years have been financially disastrous to me and sickness has been the order of the day for me both with my wife and myself'. He found himself 'badly in debt to business people' forced to live on $£ 117 \mathrm{~s}$ 8d (November 1933), $£ 34 \mathrm{~s} 9 \mathrm{~d}$ (December 1933) and $£ 1$ 1s $6 \mathrm{~d}$ (January 1934). Conveying awareness of his breadwinning role, he wrote of insufficient funds 'to live on and keep my family'. Despite illness and debt, Miers remained confident of future success, informing the enquiry: 'I would very much like to get an extension of time of some kind if no other benefit. With any kind of a fairly good run of seasons I could pull up'. ${ }^{42}$ His rent was reduced, and as the seasons improved, so did his fortune, and the family stayed in Thangool. Alice died in 1947 aged 45, and Edward in 1958, aged 63, in Yeppoon. ${ }^{43}$

Miers became the embodiment of rural masculine mythology, whereby men would transform the land, against the odds, through hard work, fortitude and endurance. ${ }^{44}$ As Holmes shows in the Mallee region of southern Australia, these Callide Valley men were considered the 'defining emblem of Australian masculinity, the white, heterosexual' nation-building pioneer. ${ }^{45}$ Settlers were very likely aware of the masculine characteristics to which they were supposed to aspire and perform. The government's promotion of the Callide Valley scheme emphasised a gendered rural ideal, where the land would be populated with white, male British settlers full of 'grit, determination, perseverance, and energy', and succeed as farmers, husbands and fathers. ${ }^{46}$ Local newspapers emphasised the toil, vigour, optimism and grit

\footnotetext{
40 This idea was discussed in relation to drought by Jones, 'Uncertainty and the Emotional Landscape of Drought'. 41 Australia, Birth Index registration numbers 002699 and 002152; Australia, Marriage Index, 1788-1950, registration number 003133; Electoral Roll, Queensland, 1937, Capricornia, Gladstone, 78.

42 Edward Meirs, Confidential Reports of Selectors. ID 1013662. QSA.

43 'Thanks Notices', Morning Bulletin, 22 November 1947, 6.

44 For a discussion of archetypal Australian pioneer, see J. B. Hirst, 'The Pioneer Legend', Historical Studies 18, no. 71 (1978): 316-37, doi.org/10.1080/10314617808595595.

45 Holmes, 'The "Mallee-Made Man".

46 Queensland Government Intelligence and Tourist Bureau, The Upper Burnett and Callide Valley Districts, Queensland (1925), 17.
} 
required of settlers. ${ }^{47}$ In 1930 s rural Queensland's patriarchal settler society, the gender ideal was a breadwinning male, with women and children supported by a man's labour, sweat and toil. Judging by the correspondence submitted to the enquiry, these descriptions offered male settlers their personal barometer of success. This phenomenon of conformity has been noted by Edward Thompson and Patrick Whearty in their study of older men in Massachusetts, which found they adhered to 'gender scripts' depicting a 'culturally idealised form of masculinity' even when their own experience disproved or defied them. ${ }^{48}$ As the enquiry submissions suggest, settler men in the Callide Valley were all too aware of the expectation to conform to masculine stereotypes.

Nevertheless, the letters reveal that some male settlers, including Joseph Toyne, did not conform. Toyne had worked his 249-acre (101-hectare) farm at Kariboe Creek, Thangool, since 1927, but it proved 'very rough and broken land with heavy boulders in places'. Despite these conditions, he had 33 dairy cows and was growing cotton, maize and pumpkins. Drought reduced his stock to 15 milking cows together with five horses, three of which died through lack of grass. Toyne owned a hut and shed with a combined valued of $£ 35$, but was heavily in debt ( $£ 249$ to the Agricultural Bank, $£ 50$ to the Department of Labour and Industry and about $£ 30$ to the Land Administration Board). With his net income falling from $£ 125$ in 1929 to $£ 60$ in 1933 , servicing these loans proved an impossibility. Toyne unrealistically planned to acquire an adjoining property, as his neighbour had been admitted to the 'lunatic asylum', leaving his land overrun with dingoes and wallabies that ate Toyne's cotton crop. ${ }^{49}$

Borrowing additional money was Toyne's solution. He requested via the enquiry a further Agricultural Bank loan to instal a water pump to improve the cows' water supply, which he hoped would enhance their cream quality. Cattle had already polluted the nearby Karaboe Creek and spread Noogoora burr throughout his property. Toyne complained of spending several weeks a year 'clearing up burrs', and he requested the rent be halved as 'we have had four bad out of eight years'. He wished to 'sell out to anybody at a reasonable valuation' or alternatively acquire more land, believing a larger holding to be more viable. It seems Toyne entertained any way out of his situation. ${ }^{50}$

47 Morning Bulletin, 20 September 1930, 11.

48 Edward H. Thompson and Patrick M. Whearty, 'Older Men's Social Participation: The Importance of Masculinity Ideology', Journal of Men's Studies 13, no. 1 (2004): 6, doi.org/10.3149/jms.1301.5. For a discussion of gendered scripts, see Gabriela Spector-Mersel, 'Never-aging Stories: Western Hegemonic Masculinity Scripts', Journal of Gender Studies 15, no. 1 (2006): 67-82, doi.org/10.1080/09589230500486934.

49 Joseph Toyne, Confidential Reports of Selectors. ID 1013823. QSA.

50 Ibid. 
Toyne presented himself as a hard-working deserving farmer, failing only as a result of his neighbours, pests or the climate. Meanwhile, his family's circumstances proved too much for his wife, Harriet Alice Toyne (née Winship). By 1932 she could stand it no more, and left. Toyne lodged a notice in the Queensland Police Gazette reporting her missing, 'with the object of inducing her to return and live with him'. ${ }^{51}$ His pleas appear to have been fruitless, as by October 1932 police thought Harriet had moved to New South Wales. ${ }^{52}$ Last seen in Gatton, southern Queensland, in 1934, her subsequent whereabouts unknown, Joseph launched divorce proceedings in the Supreme Court in March 1938 on the grounds of desertion. ${ }^{53}$ Harriet Toyne's voice is silent in the correspondence, leaving us only to surmise the unhappiness that forced her to leave her husband and at least one child behind. The year deteriorated further for Joseph when his 16-year-old son, Joseph William Toyne, died on 21 November after being bitten by a brown snake while chipping (weeding) cotton on the family farm. ${ }^{54}$ Poverty, marital breakdown, desertion and death were likely to have tested Toyne's expected stoicism and his stereotypical 'masculine' roles as a farmer, husband and father.

A sense of personal failure as a father and provider was a common thread in the correspondence to the enquiry. George McKenzie wrote that his family had been living on government relief when he selected a 1,307-acre (529-hectare) block, the $£ 5$ deposit lent by a friend. He hoped farming would 'better' his position. His wife (Evelyn) and their five children under the age of 11 moved to the region in April 1932, arriving with an axe and a brush hook, 'not even a tent'. The family survived on weekly government rations, which McKenzie collected in Biloela every fortnight, a two-day walk away. In September his wife fell ill and was hospitalised in Monto, leaving a bill of $£ 815 \mathrm{~s}$. McKenzie borrowed more money and paid five men too much to fell 50 acres ( 20 hectares) of scrub. Having been flooded the previous winter, his attempts to clear his field prior to planting through burning failed, and despite hopes to produce 50 bales of cotton, he produced only seven bales of seed cotton and 17 bales of 'snap' cotton that was considered low grade. Their sale barely covered costs. The family became reliant on storekeepers' and butcher's credit ( $£ 25$ and $£ 5$, respectively). Worse still, McKenzie chopped his foot with an axe, making him dependent on his wife and an employee (an 'old man') as cotton pickers. One of his children died, which in part he blamed on himself as 'it may not have happened if I had a conveyance of some kind'. His debts reached over $£ 400$ in 1934 and the family endured 'hardship'. His letter concluded: 'I shall have very

51 Queensland Police Gazette, 16 July 1932, 269.

52 Ibid., 1 October 1932, 368.

53 'Petition for Divorce', Evening News [Rockhampton], 2 March 1938, 1.

54 'Youth dies from snakebite', Evening News, 21 November 1938, 1. 
little cotton so I cannot see how I am going to pay even private debts..$^{55}$ Left with an injury, grief and guilt, caring for his sick wife and children and unable to meet his obligations as a provider, Mackenzie felt utterly helpless.

Illness also aggravated Joseph Maguire's woes. His land comprised 1,708 acres (691 hectares) at Thangool, generally poor country, where the scrub provided 'wallaby dens'. His agricultural efforts having failed, his only income was $£ 118$ s for felling timber. He left his wife and five children in search of work, but was injured by a fall from a horse. Tellingly, he wrote: 'together with the continual struggle for existence my health has again broke down'. After applying for a loan, Maguire 'heard nothing'. He explained: 'for eighteen months we have had no money leaving myself wife and children without clothes or blankets for the coming winter and no prospects'. In accordance with his lease, he requested government permission to pick cotton with his family elsewhere until the loan was granted. ${ }^{56}$ The land and poverty had been his undoing. He hoped his application for financial assistance would be considered favourably 'owing to what myself and family have had to contend with such as depression, drought, sickness etc'. Both McKenzie and Maguire willingly conveyed their physical health problems, but only hinted at the family's precarious mental state with a mention of depression.

In 1934 the settler O. J. Plant had reached breaking point, crippled with debt, and requested permission to sell up. He had acquired his block by ballot in 1931, an area of 2,370 acres (959 hectares) 13 miles $(21 \mathrm{~km})$ from Biloela. ${ }^{57} \mathrm{He}$ received his monthly cream cheque, but after deductions for the Agricultural Bank and cartage, 'to say nothing of rents, rates and bank dues', he could not earn 'a decent living for a single man let alone a man with a wife and 6 children'. He wrote: 'I cannot keep things together at $£ 4.13 .6$ a month so therefore I have no alternative but to get out and look for a living elsewhere and leave my wife to manage as best she can with the cows in the hope that things might brighten up.' He added: 'this state of affairs cannot carry on for too long..$^{58}$

In her work on soldier settlements in Australia, the historian Marilyn Lake notes that absences from the farm risked land forfeiture as the government considered this a 'moral and economic offence', a distraction from the core business of managing the farm..$^{59}$ In Plant's case, the government was unlikely to have favourably considered off-farm work, especially when it meant leaving his family to manage alone. Plant could see no alternative. In his mind, all his previous work had 'gone for nothing and the struggle to carry on this year to get a crop ready [has been] so hard that I feel

55 George McKenzie, Confidential Reports of Selectors. ID 1013685. QSA.

56 Joseph Maguire, Confidential Reports of Selectors. ID 1013646. QSA.

57 'The Successful Applicant', The Telegraph [Brisbane], 10 February 1931, 8.

58 O. J. Plant, Confidential Reports of Selectors. ID 1013728. QSA.

59 Marilyn Lake, The Limits of Hope: Soldier Settlements in Victoria, 1915-1938 (Melbourne and New York: Oxford University Press, 1987), 78. 
too disheartened and fed up with the whole affair to want to carry on further and I will be much more pleased if you will give me the permission to sell out'. Plant cut his losses and sold his property in February $1938 .{ }^{60}$ Leaving the land, after investing funds and years of hard work, may have been difficult and felt deeply, but some had no choice.

While many were struggling, some men found the strain intolerable. P. Price, who owned Lilydale, a 475-acre (192-hectare) selection at Jambin, complained to the enquiry that with high rents on a poor class of country, no market and 'erratic rainfall', 'I simply cannot make ends meet' with existing cotton and butter prices. He faced insurmountable debt- two years' rental $(£ 32)$, interest to the Agricultural Bank, $£ 13$ in rates and $£ 40$ to the stores. He was growing desperate: 'I don't see how I am going to carry on, I have tried to sell out, at a gift price, but no buyers, if I cannot get straight this year, well I will walk off, for I am fed up with it'. ${ }^{61}$ It appears that Price's stoicism and endurance were reaching their limits, and he saw little choice but to walk away.

It is clear from the language in the correspondence that some men felt the pain of failure acutely. An Italian, R. A. Tognolini (known as Antonio), toiled tirelessly on his farm without success, his inability to provide for his family leaving him deeply despondent. After farming in northern Italy, then Victoria, Western Australia and New South Wales, Tognolini selected 210 acres ( 85 hectares) near Biloela around 1924 with $£ 78$ from property sold in Italy and a $£ 100$ Agricultural Bank loan. He informed the Commission of Inquiry:

I started in the land with [an] undaunted will to carry the proposition honourably, has it not have been [sic] for the constant help of my wife and children, although as yet young, I am not sure if I could have carried such [a] burden; unnatural I must say in as much as neither man, or women or children should be compelled to keep slaving for so many years, without a break of any kind, living in a hut unfit for the requirements of this climate for the sake of a mere living economising in everything. ${ }^{62}$

The burden of his hard labour was pushing Tognolini to breaking point.

Until 1930 it had been 'up hill all the way', with all money spent on improvements. He had some economic success growing cotton and raising dairy cows and chickens, ${ }^{63}$ and increased his land to 223 acres (90 hectares). But the economic depression set in, which Tognoloni wrote brought 'the tragic outlook that neither the man on the land or his produce is wanted, a feeling of over production at one end, and poverty on the other, while exploitation continue unchallenged'. While it is not

60 'Biloela', Morning Bulletin, 10 February 1938, 11.

61 P. Price, Confidential Reports of Selectors. ID 1013736. QSA.

62 R. A. Tognolini, Confidential Reports of Selectors. ID 1013819. QSA.

63 'Mr Antonio Tognolini', The Capricornian [Rockhampton], 8 May 1926, 49. 
clear what specific exploitation concerned Tognolini, his frustration grew. Drought followed, killing his cotton crops and 113 acres (46 hectares) of wheat in 1932, and he was forced to pay to agist cows at Jambin. As the drought continued, five cows died and he had to move the remainder further away. Rain came in 1933, but 'at the wrong time', making the work a constant battle. High rents, dues for water supply, Agricultural Bank loans, and living and working expenses proved crippling. His sense of failure was explicit: 'I have never expected another man to come and attempt where I fail'. In his words, the depression created a 'tragic outlook that neither the man on the land or his produce is wanted'. ${ }^{64}$ The environment and human experience were at odds with both the rural and masculine imaginary in early twentieth-century Queensland.

\section{Challenging masculine mythology}

Tognolini used the word 'failure', as did the German merchant, Ernst Daniel, on 632 acres (256 hectares) near Jambin. He wrote to the Minister for Lands via the enquiry, explaining his circumstances. Aged 39, Daniel won his ballot block in 1928 and moved to the district with his wife Anne (aged 38) and children Ernst ('Ernie', 10), Liselotte ('Lottie', 12) and Karl (13). Together, they sought 'to build up in this wonderful land and now [have experienced] failure for the family and especially the children, after losing [our] old family business and estate through the war and inflation. We all have done our hardest; living very modest with as good as no comfort' (Figure 2). Despite hard work for five years, he needed help as the seasons (uncertain and irregular rain) had made it possible for an 'honest and willing man' to 'make ends meet'. Daniel felt despondent as he had failed in his perceived parental responsibility to provide for his children. He wrote:

if one tries every year again, having failure after failure and still sticks to the land and job, it might be understood, that all these disappointments work out not only disheartening but nearly heartbreaking. But still we will go on, trusting to win through if our conditions could be changed. ${ }^{65}$

Daniel requested government assistance, emphasising that his self-described failure was caused by external factors.

64 R. A. Tognolini, Confidential Reports of Selectors. ID 1013819. QSA.

65 Ernst Daniel, Confidential Reports of Selectors. ID 1013453. QSA; Morning Bulletin, 5 December 1936, 15; personal communication with their granddaughter, Marlene Brennan. 


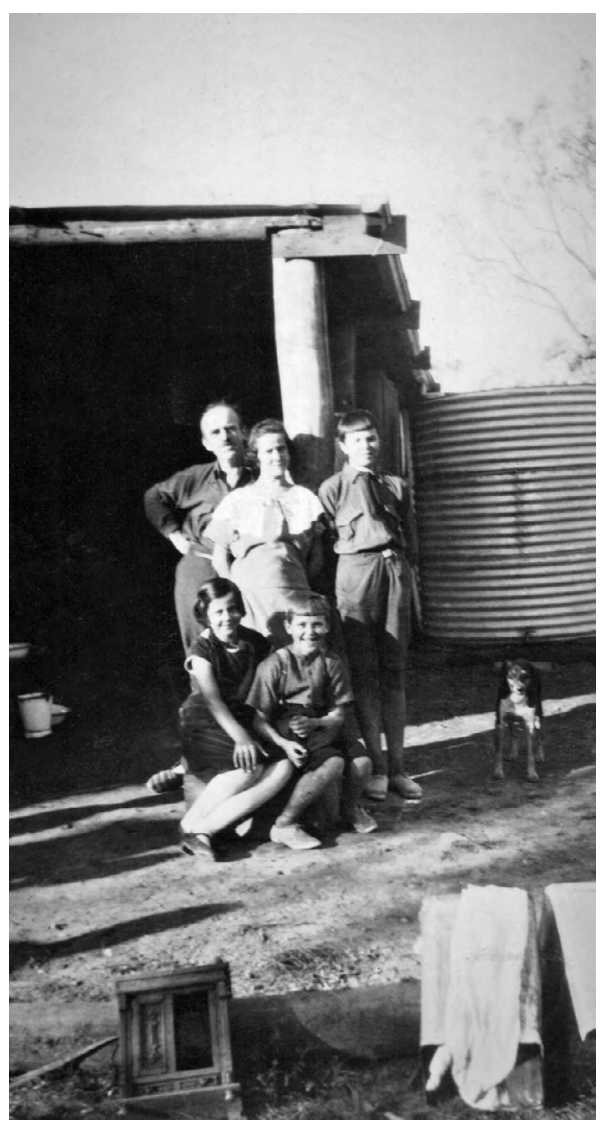

Figure 2: Ernst, Anne, Karl (standing) and Lottie and Ernie Daniel (seated) outside their modest humpy in the 1930s. A humpy is Australian slang for a small temporary shelter.

Source: Marlene Brennan, their descendant.
The Russian-born Vitally Korjenevsky was adamant- 'failure watches for me'. ${ }^{66}$ In his work on nineteenth-century Queensland, Hogg maintains that while these men did not meet culturally determined notions of manliness, it would be 'erroneous' to conclude they 'failed' as men. He points to the fluidity and complexities of notions of gender and varied forms of masculinity on the frontier to make his case. ${ }^{67}$ But in her study of 1990s Australian and New Zealand farming communities, the geographer Ruth Liepins found 'true' farmers demonstrated their masculinity by 'taming' the land through physical work to make it 'productive'. ${ }^{68}$ As the submissions to the government enquiry indicate, the dominant ideal of settler masculinity was difficult to fulfil and many Callide Valley farmers did consider themselves 'failures', as they were poor providers for their families.

In Australia's foundational stories, rural men are portrayed as courageous, stoic and determined to succeed against the elements. ${ }^{69}$ As Deb Anderson maintains in her work on drought, stoicism in the face of environmental adversity has become central to the nation's martial mythology of rural 'battlers' ${ }^{70}$ Surviving droughts, floods and pests was not an aberrant test but, instead the norm. As Jones notes, 'perseverance in

66 Vitally Basil Korjenevsky, Confidential Reports of Selectors. ID 1013617. QSA.

67 Hogg, Men and Manliness on the Frontier, 177-9.

68 Ruth Liepins, 'Making Men: The Construction and Representation of Agriculture-Based Masculinities in Australia and New Zealand', Rural Sociology 65, no. 4 (December 2000): 612-13, doi.org/10.1111/j.1549-0831. 2000.tb00046.x.

69 Russel Ward, The Australian Legend (South Melbourne: Oxford University Press, 2005).

70 Deb Anderson, 'Enduring drought then coping with climate change: Lived experience and local resolve in rural mental health', Rural Society 19, no. 4 (December 2009): 343, doi.org/10.5172/rsj.351.19.4.340. Deb Anderson, Endurance: Australian Stories of Drought (Melbourne: CSIRO Publishing, 2014), doi.org/10.1071/9781486301218. 
hardship was not only a virtual but an unavoidable reality'. ${ }^{71}$ Moreover, as work by the historian Gretel Evans on floods and bushfires reveals, enduring (and surviving) environmental disasters are regarded by some (non-Anglo) migrants as a milestone in becoming Australian. ${ }^{72}$ If failure to succeed in the Callide Valley questioned a sense of national belonging in this settlement, the stakes were high. In the mythology of nationhood and linear progress, failure has no role.

For the farmers themselves and the government, failure was not a palatable story. Holmes identifies the narrative trope of 'heroic masculinity' in the Mallee, a tale of 'battling against the odds—-both environmental and human induced—and failing through no fault of the individual'. ${ }^{73}$ This tale persisted in the Callide Valley. As in Victoria, government propaganda and newspapers celebrated (and inflated) the triumph of the settler. ${ }^{74}$ The Queensland Government had invested $£ 2$ million in a scheme of questionable success and was unlikely to concede its mistake. Farmers had endured hardship and, despite hard work, were saddled with debt. With the authors of a 1929 Queensland Government report stating that 'the scheme will not fail for want of a [sic] suitableness of the settlers' ${ }^{75}$ it took a brave (or desperate) man to admit defeat. And yet they did. The settlers, in their correspondence, frequently admit to their own inability to provide for a wife and family, and to turn a profit. Newspapers confirmed these men's distress, Rockhampton's Morning Bulletin reporting in 1933 that 'men who a few years ago, were strong and vigorous are now broken men', forced to live on relief loans ${ }^{76}$ Despite their hard work and persistence, the climate and environmental factors proved their undoing, their endurance and resilience gravely tested.

The consequences of failure were high. Lessees (usually men) who could not comply with stringent government conditions of land clearance and maintenance faced eviction. Some chose to leave the valley, despite having heavily invested their money, labour and health in the scheme, often leaving with nothing. It is not possible to determine from these records how many walked off their land. For some settlers, the outcome of the enquiry was positive, notations on some files indicating reduced rents in cases considered deserving of assistance. The scheme continued and most settlers stayed, buoyed by the eternal hope of rain and better seasons; these problems were mitigated with the introduction of irrigation in the 1960s.

\footnotetext{
71 Jones, Slow Catastrophes, 185.

72 Gretel Evans, 'Shaped by Fire: How Bushfires Forged Migrant Environmental Understandings and Memories of Place', in Disasters in Australia and New Zealand: Historical Approaches to Understanding Catastrophe, ed. Scott McKinnon and Margaret Cook (Singapore: Palgrave Macmillan, 2020), doi.org/10.1007/978-981-15-4382-1_3.

73 Holmes, 'Making Masculinity', 39-48.

74 Queensland Government Intelligence and Tourist Bureau, The Upper Burnett and Callide Valley Districts, Queensland (1925), 17; Payne, 'Report and Recommendations'; Morning Bulletin, 20 September 1930, 11.

75 Payne, 'Report and Recommendations', 14-16.

76 'Callide Valley', Morning Bulletin, 1 August 1933, 3.
} 


\section{Conclusion}

The capacity of the Callide settlement scheme to achieve nation-building goals of taming the land and defending it with white settler families relied on the importation of farmers capable of hard work, often in adverse environmental conditions. The state government advocated qualities of stoicism, grit and determination; characteristics presented in promotional literature and newspapers as intrinsically masculine and the mark of those men who would succeed on the land. In a culture that measured success in terms of conquering the environment through agriculture, failure on the family farm could be hard-felt. This was more the case where masculine ideals emphasised breadwinning, and performance of these 'male' roles was regarded as essential proof of masculinity. The pressure to succeed may have seemed relentless.

The strength of this archival collection of 955 standardised submissions (and the accompanying letters) is its record of the personal accounts of individual settler experiences. Although these were largely economic accounts for a government enquiry, the reader gains an insight into the physical and emotional hardships settlers endured as they sought to meet settler masculine ideals. Success was contingent on the environment-reliable rain, fertile soil and favourable growing conditions-factors beyond human control but exacerbated by poor government policy. Poverty, drought, floods and rudimentary living conditions took their toll. Settlers' health deteriorated, along with marital relationships. The environmental realities in the Callide Valley challenged the dominant sociocultural myths of stoic masculinity, while delusional promises of guaranteed success placed undue emotional strain on male settlers that compromised their physical and mental health.

\section{Acknowledgments}

Thanks to Marlene Brennan for providing information and photographs of the Daniel family, and the historians who attended the Gender and Environmental History workshop in December 2018 (especially Ruth Morgan and Heather Goodall), and also to the reviewers as their feedback greatly improved this article. 
This text is taken from International Review of Environmental History, Volume 7 , Issue 1, 2021, edited by James Beattie, Ruth Morgan and Margaret Cook, published 2021 by ANU Press, The Australian National University, Canberra, Australia.

doi.org/10.22459/IREH.07.01.2021.04 